DOI https://doi.org/10.30525/978-9934-26-039-1-49

\title{
ОСОБЛИВОСТІ ГАЗЕТНОЇ КОМУНІКАЦІЇ ПРО КРИЗИ
}

\author{
Терехова Л. В. \\ кандидат філологічних наук, \\ дочент кафедри лексикологї̈ та стилістики англійської мови \\ Одеського начіонального університету імені I. I. Мечникова
}

Драгомирецький О. О.

кандидат філологічних наук, дочент кафедри франиузької філології

Одеського начіонального університету імені I. I. Мечникова м. Одеса, Украӥна

Газетний текст виникає як реакція на певну поза-текстову подію, що виникла в певній ситуації. Текстова подія (подія, зображена в тексті) $є$ результатом інтерпретації суб'єктом певного фрагменту дійсності (реальної події), що має просторово-часові координати у фізичному часі та підлягає певній авторській модальності.

Матеріалом нашого дослідження є 47 статей, що з'явилися в електронних випусках газети The New York Times [1] у період 3 26.08.2019 по 13.09.2019, висвітлюючи події навколо кризової ситуації в Західній Атлантиці, спричиненої ураганом Доріан, що особливо уразив Багамські острови та загрожував іншим мешканцям регіону. В центрі уваги журналістів знаходяться події з моменту виникнення урагану до моменту його згасання. Посилання на прецедентні кризові ситуації (ураган Ірма та ураган Марія 2017 р., а також ураган Катрина 2005 р.) фіксує межі осягнення події, що переживається та висвітлюється.

Репрезентація поза-текстової події в конкретному комунікативному акті у вигляді текстової події дозволяе говорити про можливі смислові деформації: накладення локутивної мети на ілокутивні та перлокутивні цілі може призвести до викривлення масштабів події (незначна подія, висвітлена у 3МІ, має шанси стати «великою» подією, наприклад, дописи Дональда Трампа, який намагався спрогнозувати ураган точніше, ніж метеорологічна служба), або до «поляризації оцінок» (те, що поза кризою сприймається як нейтральне, у кризовій ситуації може сприйматись чи то як допомога, чи то як перешкода, як наприклад, знаходження десь на складі партії радарів, коли вони дуже потрібні для спостереження за ураганом, що наближається). 
Людина трактує кризові події як порушення звичного стану справ. У той самий час, негативні події є необхідним етапом розвитку будь-якої системи, оскільки спонукають адаптуватися до нових умов.

Серед текстових подій, вслід за В. Дем'янковим, розрізняємо головні події (фокусні) та другорядні (фонові) [2, с. 75]. Фонові події надають тексту внутрішній ритм, готують до сприйняття фокусних подій: просування урагану, очікування/переживання людей та руйнівні наслідки. Р. Кібл звертає увагу на таку закономірність: «чим серйознішими $є$ наслідки події, тим детальнішим $є$ іiі висвітлення» [3, с. 128]. Відтак, негативна інформація потребує додаткової аргументації, додаткових фактів.

Газетна комунікація про кризи відбувається в умовах дефіциту часу для всіх комунікантів. Журналіст бере на себе реалізацію функції свідка, що передбачає небезпечне наближення до кризових подій (більшість статей є доробком кількох авторів, що знаходяться в різних місцях вздовж атлантичного узбережжя Північної Америки). Він стикається 3 нестачею інформації, неможливістю концептуально охопити велике кризове явище в межах одного газетного тексту.

Зазначимо, що у кризовій ситуації відбувається певна дезорієнтація, частина звичних цінностей та станів справ відкидається, а нові цінності та стани справ виявляються ще не напрацьованими. Отже, важливим $\epsilon$ процес когнітивної адаптації, він розгортається навколо пошуку смислу події, що $є$ проблемою. Участь у кризовій ситуації зумовлено намаганням комунікантів перейти до нового врівноваженого стану системи, тобто пережити ураган. Читач публікацій про ураган Доріан керується бажанням забезпечити безпеку, для себе, своїх близьких, мінімізувати ризики пов'язані зі збігом кризової події та власного місцезнаходження в часі та просторі.

Суб'єкти кризової комунікації схильні звертатися до попереднього досвіду вирішення загрози, що виникла (так званого прецедентного феномена), а отже спиратися на смислові структури, що $є$ набагато більш організованими, зрозумілими. Тому особливістю прецедентних кризових ситуацій $є$ їхнє використання у ролі своєрідної точки часового та інтерпретаційного відліку під час розгляду інших подій. Так, влада Пуерто Ріко підготувалася до урагану Доріан, спираючись на досвід 2017 року.

Газетні тексти про кризу насичені ітеративними семантичними елементами, які розраховані на швидке читання та забезпечують змістову зв'язність. Відносно смислової зв'язності текстів у межах більш крупної комунікативної структури - макротексту - можна стверджувати, що 
мотивом для організації змісту газетних публікацій та розглядання серії статей як єдиного цілого є тематична структура [4, с. 29]. Спільність теми «кризова ситуація» (ураган Доріан) простежується між публікаціями одного номеру (горизонталь макротексту), а також між публікаціями низки послідовних номерів (вертикаль макротексту). Насиченість горизонталі макротексту статтями залежить від ступеню актуальності фокусної події на момент появи статті.

Особливість газетної комунікації про кризи полягає в тому, що окремі газетні статті не в змозі осягнути та вичерпно висвітлити усю подію, часові та просторові масштаби якої набагато перевищують можливості редакції газети. Таким чином, опис ситуації відбувається у серії публікацій, що утворюють хронологічну послідовність - макротекст. Отже, під газетним макротекстом розуміємо сукупність газетних публікацій, які присвячені одній темі, висвітлюють одну й ту саму референтну ситуацію, оприлюднені у низці номерів одного газетного видання, відзначаються узгодженістю позицій авторів та утворюють єдине комунікативне ціле [5, с. 6].

\section{Література:}

1. The New York Times. URL: http://www.nytimes.com (Дата звернення: 08.08.2020)

2. Демьянков В. 3. Семиотика событийности в СМИ // Язык СМИ как объект междисциплинарного исследования : учебное пособие. M., 2004. Ч. 2. C. 68-83.

3. Keeble R. The newspapers handbook. - London: Routhledge, 2006. 299 p.

4. Іванов В. Ф. Техніка оформлення газети: курс лекцій. - Київ: Т-во «Знання», КОО, 2000. 223 с.

5. Терехова Л. В. Газетний макротекст: єдність газетних категорій час, простір, людина в публікаціях про кризову ситуацію (на матеріалі англомовної періодики): автореф. дис. ... канд. філол. наук: 10.02.04. Одеса, 2015. 20 c. 